\title{
BENIGN OBSTRUCTION OF THE COMMON HEPATIC DUCT (MIRIZZI SYNDROME): diagnosis and operative management
}

\author{
Jaques WAISBERG, Adriano CORONA, Isaac Walker de ABREU, \\ José Francisco de Matos FARAH, Renato Arioni LUPINACCI and Fábio Schmidt GOFFI
}

\begin{abstract}
Background - Mirizzi syndrome is a rare complication of prolonged cholelithiasis, characterized by narrowing of the common hepatic duct due to mechanical compression and/or inflammation due to biliary calculus impacted in the infundibula of the gallbladder or in the cystic duct. Objectives - To describe a series of eight consecutive patients with Mirizzi syndrome, at a single institution, submitted to surgical treatment and to comment on their aspects with emphasis on the diagnosis and treatment. Methods - Four women and four men, with a mean age of 61.6 years (42 to 82 years), presenting Mirizzi syndrome were operated between 1997 and 2003. The following items were evaluated: clinical presentation, laboratory results, preoperative evaluation, operative findings, presence of choledocholithiasis, type of Mirizzi syndrome according to the classification by Csendes, choice of operative procedures, and complications. Results - The most frequent symptoms were abdominal pain $(87.5 \%)$ and jaundice $(87.5 \%)$. All the patients presented altered hepatic function tests. The diagnosis of Mirizzi syndrome was intra-operative in seven (87.5\%) patients, and preoperative in one (12.5\%). Cholecystocholedochal fistula associated with choledocholithiasis was observed in three (37.5\%) cases. Mirizzi syndrome was classified as Csendes type I in five (62.5\%) patients, type II in one (12.5\%), type III in one (12,5\%) and type IV in another (12.5\%). Cholecystectomy, as an isolated surgical procedure, was performed in four $(50.0 \%)$ patients. One $(12.5 \%)$ patient was submitted to partial cholecystectomy and closure of the fistulous orifice with the central part of the infundibula. Two $(25.0 \%)$ patients were submitted to cholecystectomy and side-to-side choledochoduodenostomy and another (12.5\%) to side-to-side choledochoduodenostomy remaining the gallbladder in situ. Seven (87.5\%) patients had an uneventful recovery and were discharged in good conditions. One (12.5\%) patient presented a postoperative sepsis due to a sub-hepatic abscess, and was reoperated. There was no operative mortality. Conclusions - The preoperative diagnosis of Mirizzi syndrome is difficult and an awarded suspicion is necessary to avoid lesions of the biliary tree. The problem may only become evident during the operation due to firm adherences around Calot's triangle. The success of the treatment is related to a precocious recognition of the condition, even at the time of surgery, and adapting the management considering to the individual characteristics of each case.
\end{abstract}

HEADINGS - Cholestasis, extrahepatic, surgery. Bile duct diseases, surgery. Cholelithiasis, surgery. Cholecystectomy.

\section{INTRODUCTION}

In 1948, the Argentinean surgeon PABLO MIRIZZI ${ }^{(17)}$, described a patient with partial obstruction of the common hepatic duct secondary to impacted biliary stone in the cystic duct or in the infundibula of the gallbladder, associated to an inflammatory response involving the cystic duct and the common hepatic duct. This presentation became known as Mirizzi syndrome.

Mirizzi syndrome is a rare complication of prolonged cholelithiasis, with prevalence from $0.05 \%$ to $2.7 \%$ among patients with calculosis of the gallbladder ${ }^{(9,10)}$. It presents a spectrum that varies from extrinsic compression of the common hepatic duct to the presence of cholecystobiliary fistula. For this reason, the disease represents a dangerous alteration in the anatomy during the performance of cholecystectomy, by predisposing the patients to the risk of an inadvertent lesion of the common hepatic duct ${ }^{(14,18,19)}$.
The difficulty surgical management of the disease is usually due to the presence of an intense fibrotic process and an eventual communication between gallbladder and common hepatic duct ${ }^{(18)}$.

The objective of this study was to describe a series of eight patients with Mirizzi syndrome, submitted to surgical treatment, and to comment on aspects of the etiopathogenesis and clinical presentation, with emphasis on the diagnosis and treatment of this complication of biliary lithiasis.

\section{METHOD}

Eight consecutive patients were operated and diagnosed with Mirizzi syndrome from November 1997 to June 2003, at the General Surgery Department, "Hospital do Servidor Público Estadual”, São Paulo, SP, Brazil. 
The clinical and morphologic information was obtained by consulting the medical records of patients included in the study and follow-up data were obtained by outpatient visits.

The inclusion criteria was characterization of Mirizzi syndrome by the presence of cholecystolithiasis and dilation of the common hepatic duct, above the level of biliary obstruction caused by impacted calculus in the cystic duct or in the gallbladder infundibula and/or inflammatory process due to the presence of biliary stones with a normal common duct diameter below the obstruction

The following data were evaluated: the clinical presentation; results of the laboratory and image exams; operative findings; presence of choledocholithiasis; type of Mirizzi syndrome according to CSENDES et al. ${ }^{(4)}$ (Table 1; Figure 1); choice of the operative procedure; and the postoperative complications. Patients with jaundice in the initial clinical presentation had their hepatic function appraised in the pre- and postoperative periods.

TABLE 1 - Classification of Mirizzi syndrome, according to Csendes et al. ${ }^{(4)}$

\begin{tabular}{|ll|}
\hline Csendes type & \multicolumn{1}{c|}{ Characteristics } \\
\hline Type I & $\begin{array}{l}\text { Extrinsic compression in the common hepatic duct by stones } \\
\text { generally impacted in the cystic duct or in the infundibula of the } \\
\text { gallbladder } \\
\text { Presence of cholecystobiliary fistula with a diameter one third of } \\
\text { the circumference of the common hepatic duct wall }\end{array}$ \\
Type III & $\begin{array}{l}\text { Presence of cholecystobiliary fistula with a diameter over two thirds } \\
\text { of the circumference of the common hepatic duct wall }\end{array}$ \\
Type IV & $\begin{array}{l}\text { Presence of cholecystobiliary fistula which involves the entire } \\
\text { circumference of the common hepatic duct wall }\end{array}$ \\
\hline
\end{tabular}

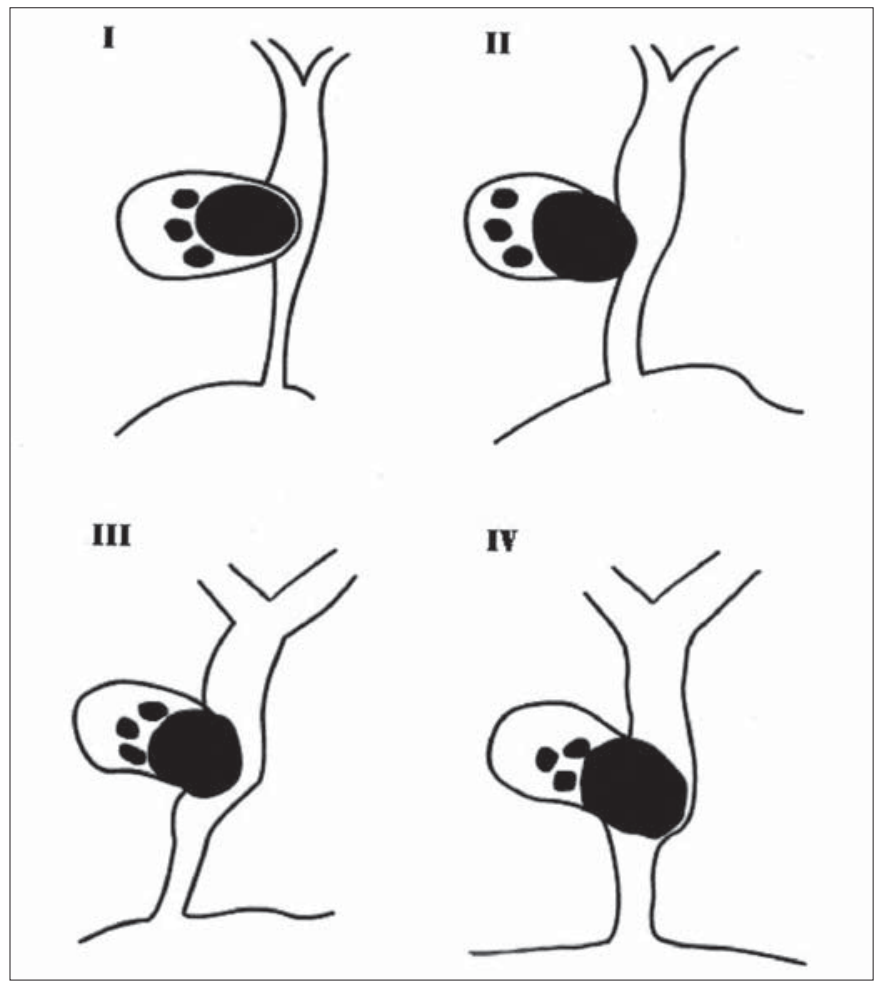

FIGURE 1 - Schematic representation of Csendes classification for Mirizzi syndrome
The quantitative variables were represented by absolute frequency (N) and relative frequency (\%). Considering the sample size, data are given as the percentage and mean.

\section{RESULTS}

Four $(50.0 \%)$ patients were female and four $(50.0 \%)$ male (Table 2 ). The mean age was 61.6 years (42 to 82 years). All the patients were white.

TABLE 2 - Principal clinical, diagnostic and operative characteristics of patients with Mirizzi syndrome

\begin{tabular}{|c|c|c|c|c|c|c|}
\hline Case & Sex & $\begin{array}{l}\text { Age } \\
(\mathrm{yr})\end{array}$ & Jaundice & $\begin{array}{l}\text { Csendes } \\
\text { type }\end{array}$ & Choledocolithiasis & Type of operation \\
\hline 1 & M & 56 & Yes & I & No & Cholecystectomy \\
\hline 2 & $\mathrm{~F}$ & 42 & No & I & No & Cholecystectomy \\
\hline 3 & M & 82 & Yes & III & Yes & $\begin{array}{c}\text { Cholecystectomy }+ \\
\text { choledochoduodenostomy }\end{array}$ \\
\hline 4 & $\mathrm{~F}$ & 52 & Yes & I & No & Cholecystectomy \\
\hline 5 & M & 53 & Yes & I & No & Cholecystectomy \\
\hline 6 & $\mathrm{~F}$ & 70 & Yes & IV & Yes & Choledochoduodenostomy \\
\hline 7 & $\mathrm{~F}$ & 65 & Yes & I & No & $\begin{array}{c}\text { Cholecystectomy + } \\
\text { choledochoduodenostomy }\end{array}$ \\
\hline 8 & M & 73 & Yes & II & Yes & $\begin{array}{l}\text { Cholecystectomy + closure } \\
\text { the fistula's orifice }\end{array}$ \\
\hline
\end{tabular}

The most frequent signs and symptoms are shown in Table 3. The mean values for the hepatic function exams concerning the patients with jaundice $(\mathrm{n}=7)$ are given in Table 4 .

TABLE 3 - Signs and symptoms most frequently presented by patients with Mirizzi syndrome

\begin{tabular}{lll}
\hline Signs or symptoms & $\mathrm{n}$ & $\%$ \\
\hline Abdominal pain & 8 & 100 \\
Jaundice & 7 & 87.5 \\
Nausea and vomiting & 5 & 62.5 \\
Choluria & 5 & 62.5 \\
Fever & 2 & 25.0 \\
\hline
\end{tabular}

TABLE 4 - Values of the hepatic function tests in patients with jaundice and Mirizzi syndrome

\begin{tabular}{lccc}
\hline Test & Mean value & Range & $\begin{array}{c}\text { Maximum } \\
\text { normal value }\end{array}$ \\
\hline Total bilirubin (mg/DL) & 8.5 & $1.5-15$ & 1.2 \\
SGOT (UI/L) & 159.6 & $63-204$ & 46 \\
SGPT (UI/L) & 229.2 & $76-394$ & 48 \\
Alkaline phosphatase (UI/L) & 432.8 & $226-792$ & 250 \\
$\gamma$ GTP (UI/L) & 694.9 & $352-1455$ & 30 \\
\hline
\end{tabular}

SGOT = serum glutamic oxaloacetic transaminase

SGPT = serum glutamic piruvic transaminase

$\gamma \mathrm{GTP}=$ gamma glutamyl transpeptidase

The diagnosis of Mirizzi syndrome was intra-operative in seven $(87.5 \%)$ patients and preoperative in one (12.5\%) (Case 7, Table 2). Seven cases with intra-operative diagnosis were submitted, to ultrasonography (US) before the operation that revealed cholelithiasis in six $(75.0 \%)$ and choledocholithiasis with dilation of the intrahepatic bile duct in one (12.5\%) (Table 2). Two $(25.0 \%)$ of these were also submitted to abdominal tomography (CT) that showed gallstones in one case $(12.5 \%)$ 
and obstruction of the common duct in another (12.5\%). Endoscopic retrograde cholangiopancreatography (ERCP) in another two $(25.0 \%)$ patients revealed choledocholithiasis and a papillotomy was performed for removal of the stone from the common hepatic duct. In one patient (12.5\%) (Case 7, Table 2) the diagnosis of Mirizzi syndrome was reached preoperatively by abdominal US (Figure 2), abdominal CT (Figure 3) and ERCP (Figure 4) that revealed fixed calculus in the infundibula area of the gallbladder, close to the junction of the cystic duct and the hepatic duct, and dilation of the intra and extrahepatic biliary ducts above the site of the obstruction.

The surgical incision used was right subcostal in seven (87.5\%) patients and right transverse in one $(12.5 \%)$. Three $(37.5 \%)$ patients, initially approached by laparoscopy, were operated using the open method.

The intra-operative findings showed impacted stone in the infundibula of the gallbladder or in the cystic duct of all the patients in the study. Cholecystocholedochal fistula associated with choledocholithiasis was observed in three $(37.5 \%)$ cases. In four $(50.0 \%)$ patients the cystic duct was isolated, while in three $(37.5 \%)$ patients the structure was not identified. Intra-operative

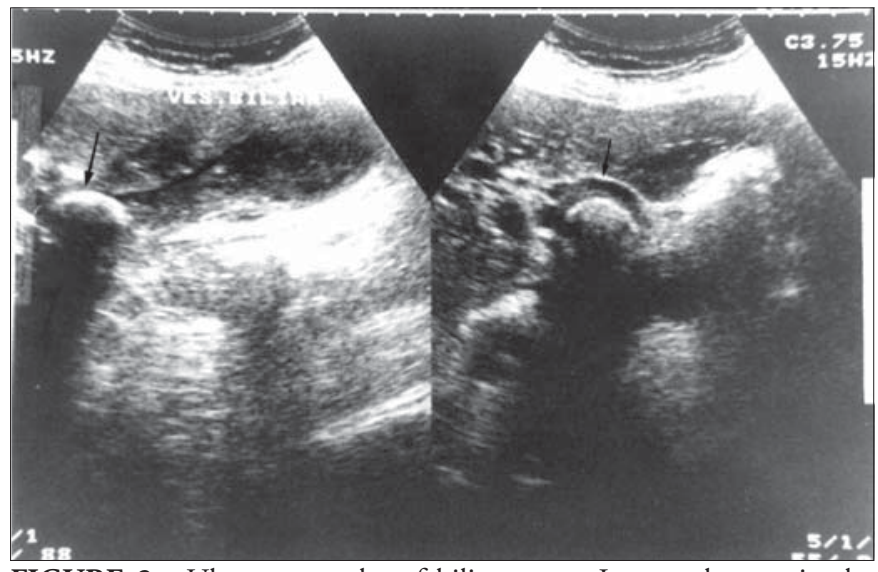

FIGURE 2 - Ultrasonography of biliary tract. Impacted stone in the infundibula of the gallbladder (large arrow) and dilatation of the common hepatic duct (small arrow)

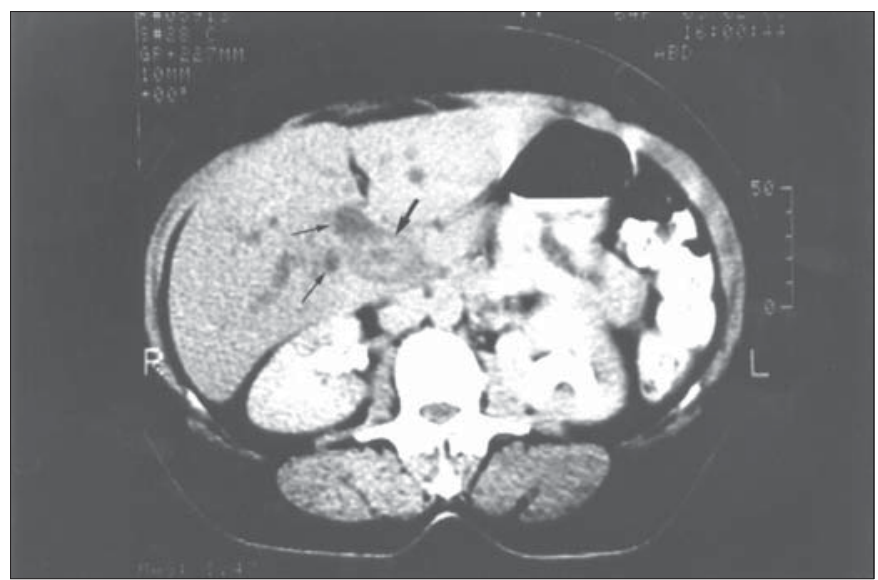

FIGURE 3 - Abdominal tomography. Dense image, compatible with lithiasis, in topography of the gallbladder infundibula and cystic duct (large arrow), associated to dilatation of the intra and extra-hepatic biliary ducts (small arrows) and hepatomegaly

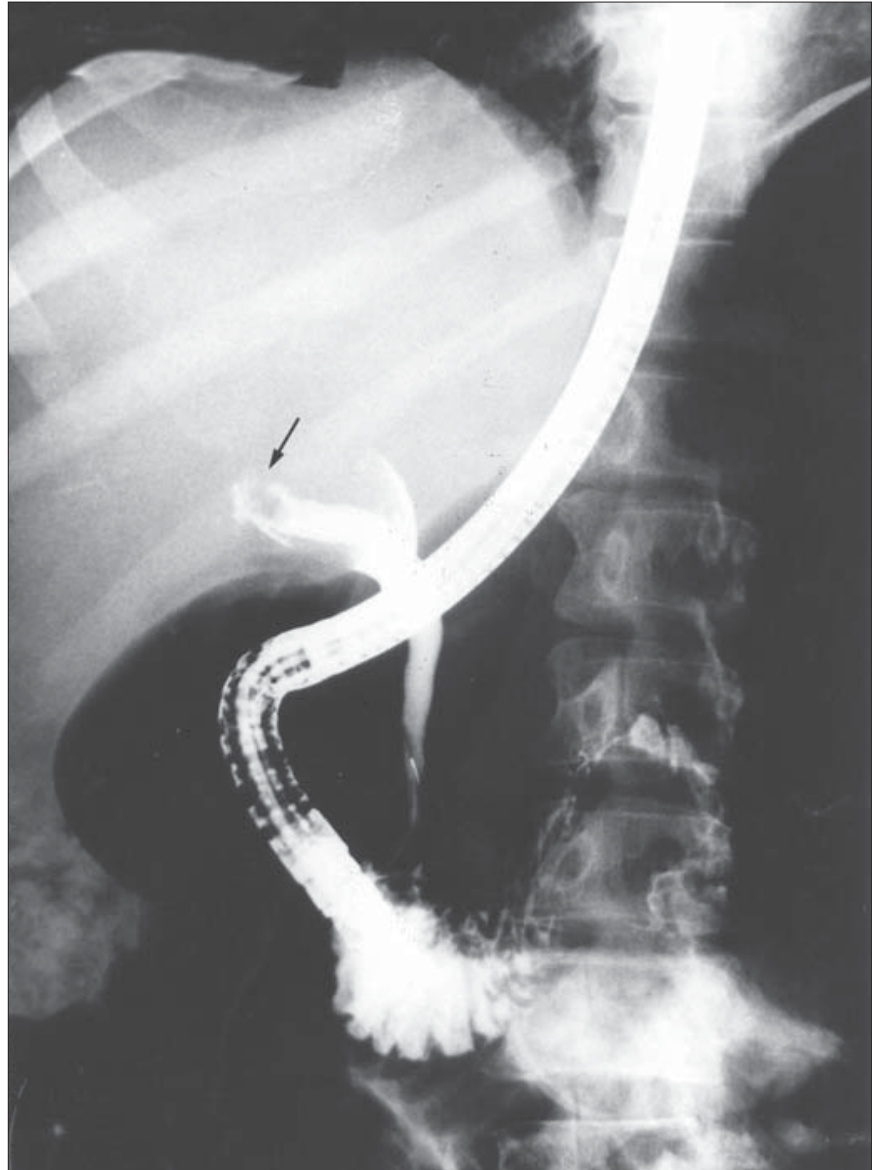

FIGURE 4 - Endoscopic retrograde cholangiopancreatography. Choledochal duct contrasted until to the common hepatic duct, with a calculus in this region (arrow)

cholangiography after removal of the gallbladder was performed in seven $(87.5 \%)$ patients, through the cystic duct in three and by puncture of the common hepatic duct with a fine needle in the other four. In five $(62.5 \%)$ patients, the intra-operative cholangiography findings did not reveal significant alterations while in one $(12,5 \%)$ the exam revealed choledocholithiasis and in other two $(25.0 \%)$ patients, the intra-operative cholangiography showed dilation greater than $2.0 \mathrm{~cm}$ in the main biliary duct and choledocholithiasis (Table 2 ). In one (12.5\%) anicteric patient, intra-operative cholangiography was not performed due to the finding of an extremely fine cystic duct that prevented its catheterization.

Mirizzi syndrome was classified, according to CSENDES et al. ${ }^{(4)}$, as type I in five (62.5\%) patients, type II in one (12.5\%), type III in one $(12,5 \%)$ and type IV in another one (12.5\%) (Table 2$)$.

Cholecystectomy, as an isolated surgical procedure, was performed in four $(50.0 \%)$ patients with Mirizzi syndrome Csendes type I (Table 2). One (12.5\%) patient with Csendes type II was submitted to partial cholecystectomy, closure of the orifice of the fistula in the common hepatic duct with the central part of the infundibula and insertion of T-tube for drainage above the site of the repair (Figure 5). Two (25.0\%) patients, one with Csendes type I and other with Csendes type III, were submitted to cholecystectomy and side-to-side choledochoduodenostomy and another (12.5\%) with Csendes type IV 


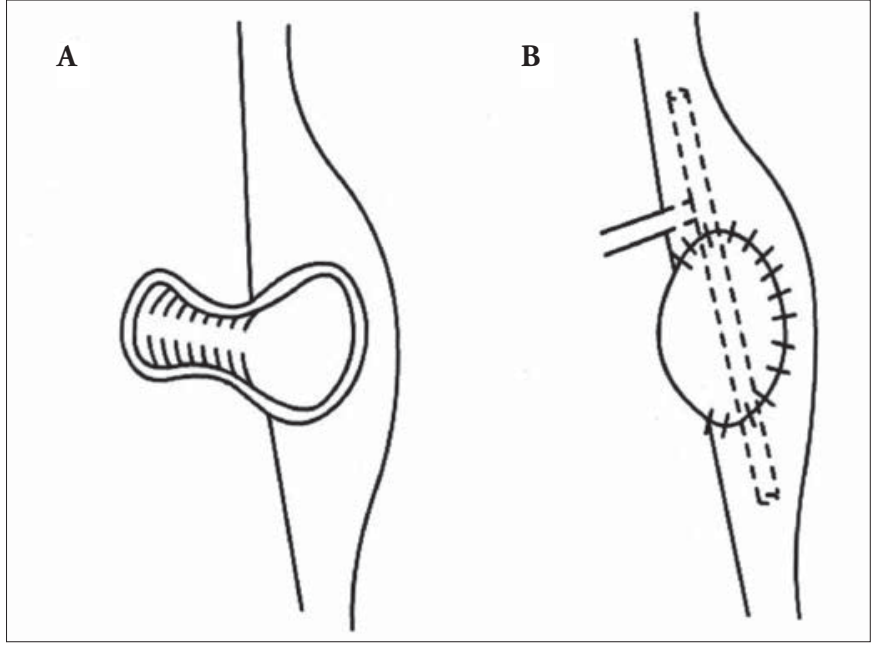

FIGURE 5 - Cholecystocholedochal fistula. A - Partial distal cholecystectomy, leaving the central part of the infundibula intact to be used when closing the fistulous orifice in the common biliary duct. B - The defect has been covered without causing a narrowing of the duct and a T-tube has been introduced above the site of the repair

to side-to-side choledochoduodenostomy, leaving the gallbladder in situ (Table 2). In the seven (87.5\%) cholecystectomized patients no malignancy was determined in any sections of the cholecystectomy specimen. In one patient (case 1) with a diffusely nodular and firm surface of the liver at laparotomy, an intra-operative hepatic biopsy revealed cholestasis with an obstructive pattern of the large biliary ducts and chronic alcoholic hepatopathy. The macroscopic appearance of the other patients' liver was normal and these were not submitted to intra-operative hepatic biopsy. The common hepatic duct was drained in three $(37.5 \%)$ cases and the abdominal cavity was drained in five $(62.5 \%)$ patients.

Seven $(87.5 \%)$ patients coursed without postoperative complications and were discharged in good conditions. One (12.5\%) patient presented sepsis on postoperative day 24 , due to a sub-hepatic abscess and was reoperated. An intra-operative cholangiography was performed that revealed calculus in the distal region of the choledochal duct. Four days later, the patient was submitted to ERCP and papillotomy with removal of the calculus from the common hepatic duct. This patient was discharged on postoperative day 31 . The perioperative morbidity was $12.5 \%$ and the mortality rate was zero.

Out of the seven $(87.5 \%$ ) patients with preoperative jaundice (Table 2 ), six $(75.0 \%)$ presented normalized hepatic function tests 30 days after the operation, while the remaining one $(12.5 \%)$ were normal on postoperative day 60 . None patient showed any symptoms attributable to the biliary tract. The mean duration of postoperative follow-up was 13.1 months ( 3 to 32 months).

\section{DISCUSSION}

CSENDES et al. ${ }^{(4)}$ classified Mirizzi syndrome into four types as shown in Table 1: type I represented by the presence of extrinsic compression of the common biliary duct by calculus in the area of the infundibula of the gallbladder or in the cystic duct; type II, characterized by cholecystobiliary fistula with the diameter of the orifice less than $1 / 3$ of the circumference of the common biliary duct; in type III, the orifice of the cholecystobiliary fistula has a diameter up to $2 / 3$ of the circumference of the common biliary duct; and in type IV, the cholecystobiliary fistula involves the entire circumference of the common biliary duct wall with the inflammatory process (Table 1; Figure 4). In the present study, Csendes type I prevailed and was observed in five patients, followed by types II, III and IV with one patient each.

The inflammatory process plays an important role in promoting the adherences of neighboring structures, most frequently involving the common bile duct, the duodenum and the colon ${ }^{(12,14)}$. Cholecystocholedochal fistula arises from the inflammation of the gallbladder wall and its consequent adherence and communication with the common bile duct ${ }^{(14)}$. In the present series, cholecystocholedochal fistula was verified in three cases.

Chronic inflammation of the gallbladder wall is usually found in patients with Mirizzi syndrome and may have a role in the pathogenesis of the cancer. It has been reported ${ }^{(21)}$ that the incidence of neoplasia of the gallbladder that passes unrecognized in patients with Mirizzi syndrome is significantly higher than the incidence of neoplasia of the same organ in long-standing cholelithiasis $(27 \%$ vs. $2 \%$, respectively).

There is no specific clinical or laboratory presentation for Mirizzi syndrome. Nevertheless, studies ${ }^{(11,15)}$ have shown that jaundice, abdominal pain and alterations in the serum tests of hepatic function comprise part of the presentation of Mirizzi syndrome in about $80 \%$ of the cases, as was also observed in the present study. Although jaundice and or alterations in the serum tests of hepatic function without macroscopic liver abnormalities occurred in five patients in this series, they were not submitted to intra-operative hepatic biopsy. Nevertheless, we advocate intra-operative hepatic biopsy whenever jaundice and or alterations in the serum tests of hepatic function are found. One patient (case 1) presented jaundice and diffusely nodular and firm surface of the liver at laparotomy, an intra-operative hepatic biopsy was performed that revealed a chronic alcoholic hepatopathy. In fact, chronic hepatopathy can lead to the formation of biliary calculus due to the hypersecretion of bilirubin and especially excess of monoglycuronil-bilirubin. That nonconjugative mono-hydrogenated bilirubin is formed by the endogenous enzymatic action of a $\beta$-glycuronidase. Due to the hypersecretion of bilirubin, precipitation of calcium bilirubinate begins in bile ${ }^{(3,13)}$.

The diagnosis can be suggested when US or abdominal CT features reveal biliary stones in the junction of the cystic and common hepatic ducts and associated to dilation proximal to the biliary tree ${ }^{(8)}$. However, a dilated cystic duct can be confused with the common hepatic duct of normal diameter ${ }^{(25)}$, thereby hindering the diagnosis of this condition. We also verified such difficulty in the present study, where an exact preoperative diagnosis obtained and abdominal CT was only achieved in one out of eight patients.

Cholangioresonance is a useful method for diagnosis of Mirizzi syndrome. Cholangioresonance can demonstrate with precision the presence of biliary dilation, the degree of obstruction, the intraluminal or external location of the biliary stones, and also identifies and evaluates the degree of inflammation around the gallbladder ${ }^{(1,7,28)}$. Cholangioresonance also can reveal extrinsic narrowing of the common bile duct, complications such as fistula and helps to show anatomical variants and malformations $\mathrm{s}^{(1,7,28)}$. 
ERCP or percutaneous transhepatic cholangiography can reveal narrowing or compression of the common hepatic duct ${ }^{(5)}$. In one patient of the present study, ERCP was performed in the preoperative period and confirmed the diagnosis of Mirizzi syndrome.

During the intra-operative, the presence of Mirizzi syndrome can be suggested by the finding of intense adhesion between the gallbladder and the common hepatic duct in the area of Calot's triangle $\mathrm{e}^{(9,27)}$.

Surgical treatment of Mirizzi syndrome includes the following important steps: careful dissection of the biliary structures; complete removal of the stones from the biliary tract; and identification of the common hepatic duct ${ }^{(16,20)}$. Intra-operative cholangiography should be performed whenever possible, especially in cases without a defined preoperative diagnosis or whenever Mirizzi syndrome is suspected during the operation ${ }^{(10,30)}$.

In the absence of cholecystobiliary fistula (Csendes type I), cholecystectomy and removal of the biliary stones constitute the treatment of choice ${ }^{(9,19)}$. In the presence of lithiasis in the common biliary duct and when choledochotomy presents technical difficulties, postoperative ERCP with extraction of the calculus can offer a safer alternative ${ }^{(2,5)}$ as occurred with one patient in the present series.

Complete removal of the gallbladder of patients with Mirizzi syndrome can be difficult to achieve due to inflammation around Calot's triangle ${ }^{(11)}$. An exhaustive dissection of the cystic duct and exposure of Calot's triangle can lead to the opening of a previously existent fistula or to the iatrogenic creation of a communication between the gallbladder and the common bile $\operatorname{duct}^{(9,19)}$. To avoid lesion of the common biliary duct, a partial cholecystectomy can constitute a safe alternative in the more complex cases ${ }^{(9)}$. This management was employed in one of our cases with Mirizzi syndrome Csendes type II. In the present series, a complete removal of the gallbladder was performed in others six patients. In the remaining patient with Mirizzi syndrome Csendes type IV, the organ was left in situ due to the absence of dissection planes between the gallbladder, the common hepatic duct and the duodenum and to avoid iatrogenic lesion of the biliary ducts.

Concerning the Mirizzi syndrome Csendes types II and III, the dissection in the level of the cystic duct and the exposure of Calot's triangle can lead to the opening of a fistulous orifice in the common biliary duct, with insufficient tissue for a satisfactory suture $^{(9)}$. In such a situation, one of the alternatives is to use the technique proposed by SANDBLOM et al. ${ }^{(24)}$, in which an initial partial cholecystectomy is performed by anterograde via, with preservation of the infundibula, followed by opening of the bottom of the gallbladder and removal of the stones from its interior, and choledochoplasty with suture of the fistulous orifice in the wall of the remaining gallbladder using absorbable thread. The T-tube is introduced into the common hepatic duct above the repair site. The closing of the hole in the common hepatic duct should be made without tension and with the mucous membrane of the gallbladder stump juxtaposed to the mucous membrane of the duct. Using the infundibula of the gallbladder close to the orifice in the common hepatic duct has the advantage that it constitutes vascular tissue and has a mucous membrane similar to that of the biliary duct ${ }^{(24)}$. We adopted this technique with success in the patient with Mirizzi syndrome Csendes type II. However, correction of the fistulous orifice, even when performed carefully, presents a tendency to formation of fibrosis and stenosis in the suture lines in the biliary duct. If the fistula cannot be corrected primarily, a bilioenteric anastomosis may be performed ${ }^{(2)}$. While for reconstruction of the biliary duct in Mirizzi syndrome type IV, a Roux-en-Y hepaticojejunostomy or sideto-side choledochoduodenostomy is usually necessary as the initial management ${ }^{(2,4)}$. In the present study, three patients were submitted to choledochoduodenostomy: one due to difficulty in repairing the cholecystocholodochal fistula (Mirizzi syndrome type III) and two due to an advanced degree of dilation of the extrahepatic biliary duct (Mirizzi syndrome type I and IV).

Patients with jaundice in the initial clinical presentation had their hepatic function appraised in the pre- and postoperative periods. All seven $(87.5 \%)$ patients with preoperative jaundice presented normalized hepatic function tests on postoperative day 60 and no patient showed any symptoms attributable to the biliary tract. This course reflects an appropriate postoperative permeability of the biliary tract. On the other hand, the chronic obstruction of the biliary tract can cause permanent hepatic lesion, especially when there is some degree of chronic infection $^{(26)}$. In such a situation, ductal biliary proliferation is followed by portal fibrosis. However, prolonged cholestasis can lead to secondary biliary cirrhosis. When the cholestasis is alleviated there can be regression, that is usually slow, of the hepatic histological features, especially eventual fibrosis of the portal zones and disappearance of the infiltration of biliary pigments ${ }^{(29)}$.

The role of minimally invasive surgery in the treatment of Mirizzi syndrome remains controversial. Some authors ${ }^{(5,20,23)}$ consider such a condition to be inappropriate or even contraindicated for laparoscopic surgery as the adherences and inflammatory tissue in the area of Calot's triangle offer difficulty in dissection. Other authors ${ }^{(11,12,22)}$ have reported that a laparoscopic approach, especially for Csendes type I lesions, is feasible, albeit technically demanding. However, conventional laparotomy is usually necessary for the correction of cholecystocholedochal fistula ${ }^{(11)}$. In the present study, three operations with initial access by laparoscopy were converted to conventional surgery due to technical difficulties.

In patients with Mirizzi syndrome and a high operative risk, satisfactory results can be obtained either through biliary drainage by endoscopic papillotomy and placement of a biliary endoprothesis or nasobiliary catheter associated with electrohydraulic lithotripsy by cholangioscopy ${ }^{(2)}$. These procedures usually relief the cholangitis and the local inflammatory process, prepare the patient for subsequent surgical intervention and serve as a guide to avoid lesion of the biliary ducts ${ }^{(12)}$.

With regard to perfecting diagnostic methods for biliary disease, Mirizzi syndrome continues to be a challenge for the surgeon. The condition may not be recognized by routine preoperative image exams and the problem only become evident at the moment of the operation in the form of firm adherences around Calot's triangle. The major factor for the successful treatment of Mirizzi syndrome is its precocious recognition, even in the intra-operative, and on the modification of the management, according to the characteristics of each case.

\section{ACKNOWLEDGMENTS}

The authors are gratefully indebted to Gabriel Morfin, Júlio Zaki Abucham Neto and Viviane Aparecida Sotto Bazalia for their helpful in this manuscript. 
Waisberg J, Corona A, Abreu IW, Farah JFM, Lupinacci RA, Goffi FS. Obstrução benigna do ducto hepático comum (síndrome de Mirizzi): diagnóstico e tratamento operatório. Arq Gastroenterol 2005;42(1):13-8.

RESUMO - Racional - A síndrome de Mirizzi, é complicação rara da colelitíase de longa duração, caracterizada pelo estreitamento do ducto hepático comum devido a mecanismo de compressão e/ou inflamação por cálculos biliares impactados no infundíbulo da vesícula biliar ou no ducto cístico. Objetivos - Descrever série de oito enfermos consecutivos com síndrome de Mirizzi de uma única instituição, submetidos ao tratamento cirúrgico e comentar seus aspectos com ênfase no diagnóstico e tratamento. Método - Quatro mulheres e quatro homens, com média de idade de 61,6 anos (42 a 82 anos), foram operados com síndrome de Mirizzi entre 1997 e 2003. Avaliaram-se a apresentação clínica, os resultados dos exames laboratoriais e de imagem, os achados operatórios, a presença de coledocolitíase, o tipo de síndrome de Mirizzi de acordo com a classificação de Csendes, a escolha do procedimento operatório e as complicações pósoperatórias. Resultados - Os sintomas mais freqüentes foram dor abdominal (87,5\%) e icterícia (87,5\%). Todos os doentes apresentaram exames de função hepática alterados. O diagnóstico da síndrome de Mirizzi foi intra-operatório em sete (87,5\%) doentes, e pré-operatório em um (12,5\%). Observou-se fístula colecistocoledociana associada à coledocolitíase em três (37,5\%) casos. A síndrome de Mirizzi foi classificada como tipo I em cinco (71,4\%) doentes, tipo II em um (14,3\%), tipo III em um (12,5\%), e tipo IV em outro (12,5\%). A colecistectomia, como procedimento cirúrgico isolado, foi realizada em quatro (50,0\%) doentes. Um (12,5\%) enfermo foi submetido a colecistectomia parcial e fechamento do orifício fistuloso com a região central do infundíbulo. Dois $(25,0 \%)$ enfermos foram submetidos a colecistectomia e anastomose coledocoduodenal látero-lateral e outro $(12,5 \%)$ a anastomose coledocoduodenal látero-lateral, deixando-se a vesícula biliar in situ. Sete (87,5\%) doentes evoluíram sem complicações pós-operatórias e obtiveram alta hospitalar em boas condições. Um $(12,5 \%)$ enfermo apresentou, no pós-operatório, sepse por abscesso sub-hepático, sendo re-operado. Não houve mortalidade operatória. Conclus̃̃es - O diagnóstico pré-operatório da síndrome de Mirizzi é difícil e é necessário elevado índice de suspeita para evitar lesões da árvore biliar. O problema pode se tornar evidente apenas no momento da operação na forma de aderências firmes ao redor do triângulo de Calot. O sucesso do tratamento está relacionado ao reconhecimento precoce da condição, mesmo no intra-operatório, e na individualização da conduta, de acordo com as características de cada caso.

DESCRITORES - Colestase extra-hepática, cirurgia. Doenças das vias biliares, cirurgia. Colelitíase, cirurgia. Colecistectomia.

\section{REFERENCES}

1. Becker CD, Grossholz M, Mentha G, de Peyer R, Terrier F. MR cholangiopancreatography: technique, potential indications, and diagnostic features of benign, postoperative, and malignant conditions. Eur Radiol 1997;7:865-74

2. Binmoeller KF, Thonke F, Soehendra N. Endoscopic treatment of Mirizzi syndrome. Gastrointest Endosc 1993;39:532-6.

3. Carey MC. Pathogenesis of gallstones. Am J Surg 1993;165:410-9.

4. Csendes A, Diaz JC, Burdiles P. Mirizzi syndrome and cholecystobiliary fistula: a unifying classification. Br J Surg 1989;76:1139-43.

5. England RE, Martin DF. Endoscopic management of Mirizzi syndrome. Gut 1997;40:272-6.

6. Figueira A, Cosentino JEM, França-Pinto PLS, Triviño T. Anastomose colédocoduodenal realizada em doentes com coledocolitíase e com estreitamento inflamatório do colédoco. Folha Méd 1998;117:71-4.

7. Fulcher AS, Turner MA, Capps GW. MR cholangiography: technical advances and clinical applications. Radiographics 1999;19:25-41.

8. Hilger DJ, VerSteeg KR, Beaty PJ. Mirizzi syndrome with common septum: ultrasound and computed tomography findings. J Ultrasound Med 1988;7:409-11.

9. Johnson LW, Sehon JK, Lee WC, Zibari GB, McDonald JC. Mirizzi syndrome: experience from a multi-institutional review. Am Surg 2001;67:11-4.

10. Karakoyunlar O, Sivrel E, Koc O, Denecli AG. Mirizzi syndrome must be ruled out in the differential diagnosis of any patients with obstructive jaundice. Hepatogastroenterology 1999;46:2178-82.

11. Kok KYY, Goh PYM, Ngoi SS. Management of Mirizzi syndrome in the laparoscopic era. Surg Endosc 1998;12:1242-4.

12. Machado MAC, Rocha JRM, Bove C, Machado MCC. Colecistectomia videolaparoscópica em paciente com síndrome de Mirizzi. Rev Hosp Clin Fac Med S Paulo 1997;52:324-7.

13. Marks JW, Bonomis GC, Alberts G, Schoenfield LJ. The sequence of biliary events preceding the formation of gallstone in humans. Gastroenterology 1992;103:566-70.

14. Martin RF, Rossi RL. Bile duct injuries. Spectrum, mechanism of injury, and their prevention. Surg Clin North Am 1994;74:781-803.

15. Martins Jr EV, Rohr MRS, Siqueira ES, Blum VF, Ferrari Jr AP. Síndrome de Mirizzi: relato de caso e revisão de literatura. GED Gastroenterol Endosc Dig 1995;14:28-30.
16. McSherry CK, Ferstenberg H, Virshup M. The Mirizzi syndrome: suggested classification and surgical therapy. Surg Gastroenterol 1982;1:219-25.

17. Mirizzi Pl. Sindrome del conducto hepatico. J Int Chirur 1948;8:731-3.

18. Nunes CCA, Peter J, Pinto RP, Grechi BLP. Síndrome de Mirizzi e fístula colecistobiliar. Rev Méd St Casa 2000;11:1983-5.

19. Pemberton M, Wells AD. The Mirizzi syndrome. Postgrad Med J 1997;73:487-90.

20. Posta GG. Unexpected Mirizzi anatomy: a major hazard to the common bile duct during laparoscopic cholecystectomy. Surg Laparoc Endosc 1995;5:412-4.

21. Redaelli CA, Buchler MW, Schilling MK, Krahenbuhl L, Ruchti C, Blumgart LH, Baer HU. High coincidence of Mirizzi syndrome and gallbladder carcinoma. Surgery 1997;212:58-63.

22. Rosello EL, Sorbello AA. Colecistectomias laparoscópicas tecnicamente complicadas. GED Gastroenterrol Endosc Dig 1991;10:111-3

23. Rust KR, Clancy TV, Warren G, Mertesdorf J, Maxwell JG. Mirizzi syndrome: a contraindication to coelioscopic cholecystectomy. J Laparoendosc Surg 1991;1:133-7.

24. Sandblom P, Tabrizian M, Fluckiger A. Repair of common bile duct defects using the gallbladder or cystic duct as a pedicled graft. Surg Gynecol Obstet 1975;140:425-32.

25. Schreiber JB, Rosenthal LE, Scovill WA, Nelson AL. The Mirizzi syndrome: preoperative diagnosis by endoscopic retrograde cholangiography. Gastrointest Endosc 1988;34:289-90.

26. Scott-Conner CE, Grogan JB. The pathophysiology of biliary obstruction and its effect on phagocytic and immune functions. J Surg Res 1994;57:316-36.

27. Shah OJ, Dar MA, Wani MA, Wani NA. Management of Mirizzi syndrome: a new surgical approach. ANZ J Surg 2001;71:423-7.

28. Soto JA, Yucel EK, Barish MA, Chutan R, Ferruci JT. MR cholangiopancreatography after unsuccessful or incomplete ERCP. Radiology 1996;199:91-8.

29. Vitale GC, Siow Y, Baker PR, Cuchierri A. Reversible bile acid changes in bile duct obstruction and its potential for hepatocelular injury. J Hepatol 1992;14:566-70.

30. Yasojema EY, Souza EAC, Yokouama MY. Colangiografia per-posperatória na colecistectomia videlaparoscópica. Rev Para Med 1999;13:17-22.

Recebido em 20/4/2004 Aprovado em 12/8/2004. 